events or malignancies were reported in the study through Week 24 for PBO and through Week 52 for BARI group. No unexpected safety signals were observed.

Table 1. Study RA-BALANCE efficacy measures

\begin{tabular}{|c|c|c|c|c|c|}
\hline & \multicolumn{2}{|c|}{ Week 12} & \multicolumn{2}{|c|}{ Week 24} & \multirow{2}{*}{\begin{tabular}{|c|} 
Week 52t \\
BARI \\
(N=145)
\end{tabular}} \\
\hline & \begin{tabular}{|c|} 
PBO \\
$(\mathrm{N}=145)$
\end{tabular} & $\begin{array}{c}\text { BARI } \\
(\mathrm{N}=145)\end{array}$ & $\begin{array}{c}\text { PBO } \\
(\mathrm{N}=145)\end{array}$ & $\begin{array}{c}\text { BARI } \\
(\mathrm{N}=145)\end{array}$ & \\
\hline ACR20, $n(\%)$ & $\begin{array}{c}41 \\
(28.3)\end{array}$ & $\begin{array}{c}85 \\
(58.6)^{+2 *}\end{array}$ & $\begin{array}{c}47 \\
(32.4)\end{array}$ & $\begin{array}{c}93 \\
(64.1)^{\operatorname{mat}}\end{array}$ & $\begin{array}{c}91 \\
(62.8)\end{array}$ \\
\hline ACR50, $n(\%)$ & $\begin{array}{c}12 \\
(8.3)\end{array}$ & $\begin{array}{c}44 \\
(30.3)^{m \times}\end{array}$ & $\begin{array}{c}17 \\
(11.7)\end{array}$ & $\begin{array}{c}56 \\
(38.6)^{\operatorname{man}}\end{array}$ & $\begin{array}{c}68 \\
(46.9)\end{array}$ \\
\hline ACR70, $n(\%)$ & $\begin{array}{c}2 \\
(1.4)\end{array}$ & $\begin{array}{c}14 \\
(9.7)^{* *}\end{array}$ & $\begin{array}{c}6 \\
(4.1)\end{array}$ & $\begin{array}{c}27 \\
(18.6)^{+20+0}\end{array}$ & $\begin{array}{c}36 \\
(24.8)\end{array}$ \\
\hline DAS28-hsCRP $\leq 3.2, \mathbf{n}(\%)$ & $\begin{array}{c}13 \\
(9.0)\end{array}$ & $\begin{array}{c}36 \\
(24.8)^{\operatorname{san}}\end{array}$ & $\begin{array}{c}15 \\
(10.3)\end{array}$ & $\begin{array}{c}51 \\
(35.2)^{n+\infty}\end{array}$ & $\begin{array}{c}67 \\
(46.2)\end{array}$ \\
\hline DAS28-hsCRP <2.6, n (\%) & $\begin{array}{c}4 \\
(2.8)\end{array}$ & $\begin{array}{c}17 \\
(11.7)^{2 *}\end{array}$ & $\begin{array}{l}10 \\
(6.9)\end{array}$ & $\begin{array}{c}21 \\
(14.5)^{*}\end{array}$ & $\begin{array}{c}48 \\
(33.1)\end{array}$ \\
\hline CDAI $\leq 10, n(\%)$ & $\begin{array}{c}13 \\
(9.0)\end{array}$ & $\begin{array}{c}26 \\
(17.9)^{*}\end{array}$ & $\begin{array}{l}13 \\
(9.0)\end{array}$ & $\begin{array}{c}39 \\
(26.9)^{\mathrm{mat}}\end{array}$ & $\begin{array}{c}67 \\
(46.2)\end{array}$ \\
\hline SDAI s11, n (\%) & $\begin{array}{l}12 \\
(8.3)\end{array}$ & $\begin{array}{c}30 \\
(20.7)^{* *}\end{array}$ & $\begin{array}{l}14 \\
(9.7)\end{array}$ & $\begin{array}{c}40 \\
(27.6)^{\operatorname{mat}}\end{array}$ & $\begin{array}{c}67 \\
(46.2)\end{array}$ \\
\hline HAQ-DI MCID $\geq 0.22, n(\%)$ & $\begin{array}{c}89 \\
(61.4)\end{array}$ & $\begin{array}{c}102 \\
(70.3)\end{array}$ & $\begin{array}{c}51 \\
(35.2)\end{array}$ & $\begin{array}{c}94 \\
(64.8)^{\operatorname{sen} x}\end{array}$ & $\begin{array}{c}89 \\
(61.4)\end{array}$ \\
\hline HAQ-DI MCID $\geq 0.3, n(\%)$ & $\begin{array}{c}67 \\
(46.2)\end{array}$ & $\begin{array}{c}90 \\
(62.1)^{\mu * *}\end{array}$ & $\begin{array}{c}45 \\
(31.0)\end{array}$ & $\begin{array}{c}85 \\
(58.6)^{200}\end{array}$ & $\begin{array}{c}83 \\
(57.2)\end{array}$ \\
\hline $\begin{array}{l}\text { LS mean } \Delta \text { Patient's Assessment of Pain } \\
(0.100 \mathrm{~mm} \mathrm{VAS})^{*}\end{array}$ & -17.7 & $-31^{n+x}$ & -20.1 & $-34.8^{\operatorname{san} x}$ & -40.2 \\
\hline $\begin{array}{l}\text { LS mean } \Delta \text { Patient's Global Assessment of Disease Activity } \\
(0.100 \mathrm{~mm} \text { VAS })^{s}\end{array}$ & .20 .0 & $-31.3^{n+\infty}$ & -18.5 & $-33.4^{4+\infty}$ & -37.8 \\
\hline
\end{tabular}

PBO, placebo; BARI, baricitinib; MCID, minimum clinically important difference; VAS, visual analogue scale. Patients received stable background MTX throughout the study. Data are \% patients (NRI), u
"Data are least-squares (LS) mean change from baseline; tlnitially randomized to baricitinib.

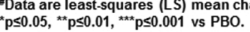

Conclusions: Compared to PBO, BARI provided significant improvements in control of signs and symptoms, including pain and physical function with an acceptable safety profile.

Disclosure of Interest: Z. Li Consultant for: Advisory board member of baricitinib, J. Hu: None declared, C. Bao Consultant for: Advisory board member of baricitinib, X. Li Consultant for: Advisory board member of baricitinib, X. Li Consultant for: Advisory board member of baricitinib, J. Xu: None declared, A. Spindler: None declared, X. Zhang Consultant for: Advisory board member of baricitinib, J. Xu Consultant for: Advisory board member of baricitinib, Z. Li Consultant for: Advisory board member of baricitinib, G. Wang Consultant for: Advisory board member of baricitinib, J. Sun Shareholder of: Eli Lilly and company, Employee of: Eli Lilly and company, F. Ji Shareholder of: Eli Lilly and company, Employee of: Eli Lilly and company, H. Tao Shareholder of: Eli Lilly and company, Employee of: Eli Lilly and company, L. Zhan Employee of: Eli Lilly and company, T. Rooney Shareholder of: Eli Lilly and company, Employee of: Eli Lilly and company, C. Zerbini Grant/ research support from: Grants for research received by my research center CEPIC, for teriparatide and baricitinib protocols, Consultant for: Advisory board member of baricitinib

DOI: 10.1136/annrheumdis-2018-eular.1983

\section{SAT0219 UPADACITINIB IN PATIENTS WITH ACTIVE RHEUMATOID ARTHRITIS AND INADEQUATE RESPONSE OR INTOLERANCE TO BIOLOGICAL DMARDS: A PHASE 3 RANDOMIZED, PLACEBO- CONTROLLED, DOUBLE-BLIND STUDY OF A SELECTIVE JAK1 INHIBITOR}

M. C. Genovese ${ }^{1}$, R. Fleischmann ${ }^{2}$, B. Combe ${ }^{3}$, S. Hall ${ }^{4}$, Y. Zhang ${ }^{5}$, Y. Zhou ${ }^{5}$, M. F. Mohamed ${ }^{5}$, S. Meerwein ${ }^{6}$, A. L. Pangan ${ }^{5} .{ }^{1}$ Stanford Univ, Palo Alto, ${ }^{2}$ Univ of Texas Southwestern, Dallas, United States, ${ }^{3}$ Montpellier Univ, Montpellier, France, ${ }^{4}$ Monash Univ, Cabrini Health \& Emeritus Res, Malvern, Australia, ${ }^{5}$ AbbVie, $N$ Chicago, United States, ${ }^{6}$ AbbVie Deutschland, Ludwigshafen, Germany

Background: Upadacitinib (UPA), an oral, selective JAK1 inhibitor was effective in ph 2 trials in rheumatoid arthritis (RA) pts with inadequate response (IR)/intolerance to csDMARDs and bDMARDs.

Objectives: To evaluate safety and efficacy of UPA in bDMARD-IR pts on stable background csDMARDs

Methods: Pts with active RA ( $T J C \geq 6, S J C \geq 6$; $h s C R P \geq 3 \mathrm{mg} / \mathrm{L}$ ) were randomized 2:2:1:1 to receive UPA $15 \mathrm{mg}$ or $30 \mathrm{mg}$ once daily (QD) or PBO for 12 wks followed by UPA $15 \mathrm{mg}$ or $30 \mathrm{mg}$ QD starting at Wk 12 . The primary endpoints were the proportion of pts achieving ACR20 (for FDA) and the proportion achieving DAS28CRP $\leq 3.2$ (for EMA) at Wk 12 (NRI).

Results: Of 499 randomized pts, 498 received study drug; 451 (90.6\%) and 419 (84.1\%) completed Wks 12 and 24 respectively. BL disease characteristics indicated long-standing severe, refractory disease: (means) duration since diagnosis 13 yrs; DAS28CRP, 5.8; TJC68, 27.9; SJC66, 16.8; 53\% experienced $\geq 2$ prior bDMARDs. At Wk 12 , more pts $(p<0.001)$ on UPA 15 and 30 vs PBO achieved the primary endpoints (ACR20: $64.6 \%$ and $56.4 \%$ vs $28.4 \%$; DAS28CRP $\leq 3.2: 43.3 \%$ and $42.4 \%$ vs $14.2 \%$ ) and other secondary endpoints (Table). Among pts with IR to multiple bDMARDs/MOAs, and pts with lack of efficacy for $\alpha-$ IL-6, the proportions achieving ACR20 on UPA vs PBO were comparable to the overall treated population. By Wk 1, more pts achieved ACR20 on UPA 15 and 30 vs PBO ( $27.4 \%$ and $24.8 \%$ vs $10.7 \%, p<0.001)$. At Wk 12 , significant improvements were observed on UPA 15 and 30 vs PBO for HAQ-DI (LSM change -0.39 and -0.42 vs $-0.17, p<0.001$ ). At Wk 24 , responses were similar or greater for pts originally on UPA and comparable for pts who switched to UPA after 12 wks of PBO

Up to wk 12, the frequency of AEs was comparable for PBO and UPA 15, but higher for UPA 30 (table 1). Overall AE rates (E/100 PY) through Wk 24 for UPA 30 were similar or slightly higher vs UPA 15; more AEs led to study drug discontinuation in UPA 30. Occurrence of infections was similar in all arms, but there were more serious infections and herpes zoster cases in UPA 30. Malignancies were reported in 3 pts over 12 wks with 1 additional case through Wk 24. Through Wk 12, pulmonary embolism (PE) was reported in 2 pts (1 each on UPA 15 and 30 ), none with DVT; through Wk 24, PE were reported in 4 more pts (UPA 15: 3, 1 of whom also had a DVT; UPA 30:1). All had risk factors for DVT/PE. 2 deaths were reported (UPA30: 1 before Wk 12; UPA 15:1 after Wk12)

\begin{tabular}{|c|c|c|c|c|c|c|c|}
\hline \multicolumn{8}{|c|}{ Efficacy Measures'; Percentage of Patients with a Response } \\
\hline & \multicolumn{3}{|c|}{ Week 12} & \multicolumn{4}{|c|}{ week 24} \\
\hline & \begin{tabular}{|l|}
$P B O$ \\
$N=169$
\end{tabular} & $\begin{array}{l}\text { UPA } 15 \\
n=164\end{array}$ & $\begin{array}{l}\text { UPA } 30 \\
N=165\end{array}$ & $\begin{array}{l}\text { PEOG } \\
\text { UPA 15 } \\
N=85\end{array}$ & $\begin{array}{c}\mathrm{PBO} \rightarrow \\
\text { UPA } 30 \\
N=84\end{array}$ & $\begin{array}{l}\text { UPA } 15 \\
N=164\end{array}$ & $\begin{array}{l}\text { UPA } 30 \\
N=165\end{array}$ \\
\hline ACR20 & 28.4 & $64.6^{* 1 *}$ & $56.4 * *$ & 51.2 & 63.1 & 61.6 & 59.4 \\
\hline DAS28-CRPS3.2 & 14.2 & $43.3^{* \cdots}$ & $424^{* \cdots}$ & 38.8 & 56.0 & 52.4 & $\$ 15$ \\
\hline ACR5O & 11.8 & $1 \cdots$ & $35.8^{*} \cdots$ & 5.3 & 38.1 & 42.7 & 3.0 \\
\hline ACR 70 & 65 & 116 & $23.0 \%$ & 2.4 & 21.4 & 22.0 & 4.2 \\
\hline COAI $\leq 10$ & 14.2 & $317 \cdots$ & $33.9^{* *}$ & 34.1 & 53.6 & 47.0 & 43.6 \\
\hline COAI $\leq 28$ & 47 & 7.9 & & & 14.3 & 10.4 & 5.2 \\
\hline DAS28-CRP $<2.6$ & 9.5 & $28.7 \cdots$ & $23.6 \cdots$ & 28. & 34.5 & 32 & 34.5 \\
\hline $\begin{array}{l}\text { ACR } 20 \text { in ots wh o f folled } 22 \\
\text { bDMARDS and } \alpha 223 \mathrm{MOA}\end{array}$ & 23.1 & 708 & 50.0 & - & - & - & - \\
\hline $\begin{array}{l}\text { ACR20 in pts with LoE for } \\
\text { anti-1L6 }\end{array}$ & 200 & 556 & 581 & - & - & - & - \\
\hline \multicolumn{8}{|l|}{ Summ ary of AEs, $n(\$ \%)$} \\
\hline & \multicolumn{3}{|c|}{ Week 0.12} & \multicolumn{4}{|c|}{ Week 12-24 } \\
\hline & $\begin{array}{c}\text { PSO } \\
N=169\end{array}$ & $\begin{array}{l}\text { UPA 15 } \\
N=164\end{array}$ & $\begin{array}{l}\text { UPA } 30 \\
N=165\end{array}$ & $\begin{array}{l}P B O \rightarrow \\
\text { UPA 15 } \\
\|=72\end{array}$ & $\begin{array}{l}P B O \rightarrow \\
\text { UPA } 30 \\
\mu=75\end{array}$ & $\begin{array}{c}\text { UPA } \\
15 \\
N=156\end{array}$ & $\begin{array}{c}\text { UPA } \\
30 \\
n=148\end{array}$ \\
\hline AES & 95 & 91 & 3) & $30(41.7)$ & $50(66.7)$ & $82(52.6)$ & $83(56.1)$ \\
\hline AE Leosin & $9(5.3)$ & $4(2$ & 15 & $2(2.8)$ & 30 & $5(3.2)$ & \\
\hline \multirow{2}{*}{\multicolumn{8}{|c|}{ Patients with Adverse fvents of Special interest, $n(\$ 0)$}} \\
\hline & & & & & & & \\
\hline Infection & $51(302)$ & $54(32.9)$ & $55(33.3)$ & $16(22.2)$ & $31(41,3)$ & $43(27.6)$ & $47(31.8)$ \\
\hline - Seria & 0 & & & $2(2.8)$ & $1(1,3)$ & $1(0.6)$ & $2(1.4)$ \\
\hline - Oppor & 0 & & & 0 & 0 & 0 & $1(0.7)$ \\
\hline - Herpe & $1(0.6)$ & $\frac{110}{110}$ & $4(2.4)$ & 0 & $1(1,3)$ & $2(1.3)$ & $2(1.4)$ \\
\hline- Tube & 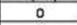 & 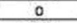 & & & & 0 & 0 \\
\hline Malignancy (exc NMSC) & 0 & $1(0.6)$ & $2(12)$ & & & $1(0.6)$ & 0 \\
\hline NMSC & 0 & 0 & 0 & 0 & 0 & 0 & 0 \\
\hline $\operatorname{trmg}$ & 0 & & & 0 & 0 & 0 & \\
\hline Hepar & $2(1.2)$ & $2(1,2)$ & $3(18)$ & 0 & $2(2.7)$ & $4(2.6)$ & $4(2.7)$ \\
\hline Gl Perforatic & 0 & 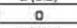 & 0 & 0 & 0 & 0 & $1(0.7)$ \\
\hline$P E$ & 0 & & 10.6 & $2(28)^{9}$ & $1(1,3)$ & $1(0.6)$ & 0 \\
\hline CV Events adjudiczed $d^{g}$ & 0 & 110.6 & 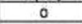 & 0 & $1(2.3)$ & $2(1.3)$ & 0 \\
\hline Deaths ${ }^{\circ}$ & 0 & 0 & $1(06)$ & 0 & 0 & $1(0.6)$ & 0 \\
\hline \multicolumn{8}{|c|}{ 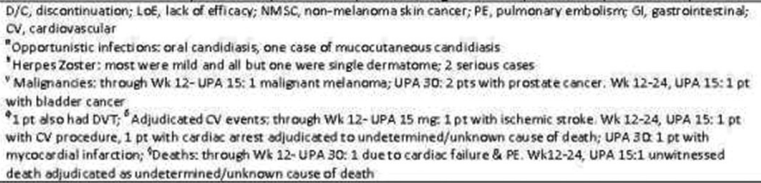 } \\
\hline
\end{tabular}

Conclusions: In this treatment-refractory, bDMARD-IR RA population, rapid, significant improvements were observed with UPA at both doses vs PBO during 12 wks of treatment, and maintained through 24 wks. Overall safety was consis tent with ph2 and other ph3 studies with UPA. The rates of PE and DVT observed in this study have not been reported for the other ph3 studies that have been unblinded to date. Overall data from the ph3 program will allow a comprehensive evaluation of the benefit:risk profile of UPA in RA.

Acknowledgements: AbbVie sponsored study design, data collection, analysis \& interpretation, writing, review, approval of final. Med writing:Naina Barretto of AbbVie

Disclosure of Interest: M. Genovese Grant/research support from: AbbVie Lilly, Pfizer, Galapagos, Gilead, Consultant for: AbbVie, Lilly, Pfizer, Galapagos, Gilead, R. Fleischmann Grant/research support from: AbbVie, Consultant for: AbbVie, B. Combe Consultant for: Abbvie, BMS, Jansen, Lilly, MSD, Pfizer Roche Chugai, UCB, S. Hall: None declared, Y. Zhang Shareholder of: AbbVie, Employee of: AbbVie, Y. Zhou Shareholder of: AbbVie, Employee of: AbbVie, M. Mohamed Shareholder of: AbbVie, Employee of: AbbVie, S. Meerwein Shareholder of: AbbVie, Employee of: AbbVie, A. Pangan Shareholder of: AbbVie, Employee of: AbbVie

DOI: 10.1136/annrheumdis-2018-eular.4180 